\title{
Racial Genealogies and Intertextuality in Contemporary Britain: Caryl Phillips's The Lost Child
}

\section{Alessia Polatti}

\section{(2) OpenEdition \\ 1 Journals}

Electronic version

URL: https://journals.openedition.org/ces/4508

DOI: $10.4000 /$ ces.4508

ISSN: 2534-6695

Publisher

SEPC (Société d'études des pays du Commonwealth)

\section{Printed version}

Date of publication: 1 September 2017

Number of pages: 105-115

ISSN: 2270-0633

\section{Electronic reference}

Alessia Polatti, "Racial Genealogies and Intertextuality in Contemporary Britain: Caryl Phillips's The Lost Child", Commonwealth Essays and Studies [Online], 40.1 | 2017, Online since 02 April 2021, connection on 25 January 2022. URL: http://journals.openedition.org/ces/4508 ; DOI: https://doi.org/ $10.4000 /$ ces. 4508

\section{(c) $(1) \odot$}

Commonwealth Essays and Studies is licensed under a Licence Creative Commons Attribution - Pas d'Utilisation Commerciale - Pas de Modification 4.0 International. 


\section{Racial Genealogies and Intertextuality in Contemporary Britain: Caryl Phillips's The Lost Child}

The aim of the paper is to examine the different family dynamics depicted in Caryl Phillips's The Lost Child (2015). In particular, it will be demonstrated how the author exploits the trope underlying the title of the novel and a web of intertextual references to Emily Brontë's Wuthering Heights in order to portray the complexity and the dramatic nature of those aspects of family relationships which derive from the social and racial dynamics of nineteenthcentury English society.

I can whistle that whole symphony now... I know every single moment, because it's about how you score emotion basically - how you move and keep a theme going. You keep going forward, but [you keep] remind[ing] us where we've been.

Caryl Phillips (Clingman 130).

In an interview with Stephen Clingman, Caryl Phillips underlines the importance of "know[ing] every single moment" while narrating a story, and the relevance of both past and present. In order to "whistle the whole symphony" and "keep a theme going," the author needs to remember where he comes from. Knowing the past means being able to understand the present: it is for this reason that in his latest novel, The Lost Child (2015), Phillips exploits the ancient trope underlying the title by adopting a familiar frame - typical of the English literary tradition ${ }^{1}-$ in order to explore the different family relationships characterizing British society from the nineteenth century to the 1960s. Therefore, even if it can be considered as a rewriting of Emily Brontë's Wuthering Heights (1847), limiting Phillips's novel to this description would be reductive. The work actually combines different stories, settings, and intertextual references, introducing them in independent chapters which establish a web of interconnections between literature and the history of Black Britain. All these elements can be seen as related to the trope of the lost child, the veritable leit-motif of the narration, and the complexity of these interrelations goes beyond a simple rewriting. In other words, Phillips is using this archetypal pattern as a framework in which to connect the past and present of British family histories, thus linking literary representation to social reality. From this perspective, the lost child helps to illuminate the rather ambiguous family relations that characterize the current multicultural British society. The complex structure of the novel serves to blur the boundary between text and intertext: the result is a disturbing portrayal of English society throughout the centuries, a depiction which starts and ends with the Brontian text and the rewriting of Heathcliff's story in the first section, "Separation," and in the last two, "The Journey" and "Going Home." Between these two poles lies a depiction of the twentieth-century multicultural society and the fictionalized

1. According to Barbara Estrin, the lost child is a very ancient myth which can be traced back to the time of Moses and King Arthur; in fact, the lost children are classically orphans or abandoned boys raised by substitute parents (The Raven and the Lark 13). The myth has often been exploited in English literature from the Renaissance to more recent times: from William Shakespeare to Emily Brontë and Charles Dickens, many authors have used it to underline the relevance of children for the construction of families' genealogies (19), especially when the stories rely on a happy ending, with the child's return to his family. 
history of Emily Brontë's family depicted in the middle of the novel. Viewed in this light, the role of intertextuality is to place a contemporary situation - the story of the Wilsons, a twentieth-century mixed family - within a historical frame represented by a novel with which people assume they are familiar - Brontë's Wuthering Heights - and the life of its author's family.

By means of a web of echoes, repetitions and ghostly traces, along with examples of dislocation across time and place, Phillips's novel raises questions of identity and belonging, memory and history. These questions haunt the various historical moments fictionalized by the text, as well as the several parts which compose the plot, connecting them in ways which are not immediately visible. Hence the story-telling of the "true" origins of Heathcliff, the orphan protagonist of Emily Brontë's novel, along with the narration of the story of the Brontë family, in particular of the difficult relationship between the head of the family, Patrick, and the son, Branwell, contribute to the reader's understanding of the novel's contemporary plot, the story of Monica Johnson, a young white woman who has been in conflict with her father Ronald since her childhood. In particular, the introduction of the Brontë family in the middle of the narration is the element of transition which allows Phillips to pass from a nineteenth-century setting to the discussion of the contemporary family's dynamics. In this way, Phillips provides an intertextual background for the interpretation of contemporary race relations, whilst he also manages to reconnect the narration of white British family relations to the history of Black Britain by narrating the story of Monica's marriage with a black Caribbean man, Julius Wilson. The interrelationship between the (contemporary) black experience and the (past) white history of the UK is embodied by their mixed marriage which results in the birth of two children, Ben and Tommy: as will be discussed shortly, their family represents a prototype of the current multicultural Britain, while at the same time it also contributes to ruining the relationship between Monica and her severe father. Hence the constant parallels between the characters' experiences shape the novel's plot, whilst they also create a complex network of correspondences, references, and echoes. As Maurizio Calbi suggests, "it is through the proliferation of these uncanny juxtapositions that the text registers the implication, as well as the reiteration, of a variety of forms of marginalization" throughout British history (48). From this perspective, the plot recalls the structure of Phillips's previous work The Nature of Blood (1997), where it is possible to recognize a fragmented scheme in which "each story presents itself in its singularity but also, at the same time, comes into its own by being the repetition of another story. There is always more than one voice speaking when each of the main characters speaks" (Calbi 48), and this is exactly what happens also in The Lost Child. Additionally, the presence of many intertextual references is another contact point between the two works ${ }^{2}$ although, in The Lost Child, the innovative element is represented by the author's desire to exploit intertextuality in order to investigate the deepest nature of one of the most archaic human bonds: the parent/child relationship.

2. The Nature of Blood and The Lost Child can be analysed together because they present a similar structure, in which the fragmentation of the narration, intertextuality, and the presence of different stories coexist in order to support a main topic which is developed throughout the centuries, and in different places. Hence, in the case of The Nature of Blood, the horror of the Shoah is connected to the racial stereotypes against Black people represented in the rewriting of Shakespearian Othello; in The Lost Child, the main topic of the lost children is used to relate the racial question to white British society and its literary canon, exemplified by Wuthering Heights. 
The trope of the "lost child" constitutes the thematic thread that is pursued throughout the different stories of the novel: it narrativizes the complexity and the dramatic nature of those aspects of family relationships which derive from the social and racial dynamics of English society from the nineteenth century to nowadays. As Estrin observes, the lost child motif is an often-used theme in English literature, and generally speaking, it was traditionally based on a protagonist's longing for an aristocratic lineage, according to which "the biological parents are superior to the adoptive ones" (The Raven and the Lark 14). This would demonstrate that nature is superior to nurture and that the interlude between loss and finding is just a temporary misfortune. In this regard, the tradition of the lost child topic implies that "knowing a background is equivalent to hav ing a future" (ibid.), and this assumption is a useful starting point to examine Phillips's work. Indeed, according to Estrin, "For Phillips, memory involves an understanding that our contemporary experience connects to our mythological past and that such an understanding requires us to read that past from the retrospect of its historical repercussions" (Mythical Lost Children 31). Chronicling historical events in the present tense and examining the experience of both the Brontë family and Emily's Wuthering Heights is for the author one way of analyzing the dynamics of twentieth-century British multiracial families. It is for this reason that Phillips constructs a cyclic narration in which characters repeat patterns from the past: the starting point for his personal reading of the lost child myth is Branwell Brontë, fictionalized by his sister Emily in the character of Heathcliff and, in turn, reflected in The Lost Child in the character of Tommy, the son of Monica. In Phillips's imagination, Branwell Brontë is portrayed as a boy who "lived with a ferocity that frightened the gods themselves, you know this, don't you? He deserved to be loved and protected, but it was the wickedness of the world that corrupted him" (The Lost Child 111), in a description which recalls the indomitable nature of Heathcliff. At the same time, Heathcliff is unfamiliar with his adopted country, an aspect of his characterization which finds an echo in the abandonment and loneliness felt by Tommy Wilson in the desolation of his mixed British family. From this perspective, Phillips has transposed the story of the foreign lost child Heathcliff into a new place - a multiracial family in Britain - and a new time - the 1960s - embodying him in the character of Tommy, a boy who refuses to be acclimatized to both his place and time, maybe because he feels that he has failed the "blood-line test that legitimates the child in the main plot of the foundling theme" (Estrin, Mythical Lost Children 43). However, while Phillips's Heathcliff is ultimately "welcome to stay" in his father's house (The Lost Child 259), as it is made clear also from the title of the final section, "Going Home," Tommy ends up succumbing to his blood, forgotten by his father and his family. Hence, assuming that "the happy ending of the traditional lost child plot depends on never forgetting (never letting one thing stand in for another[...])" (Estrin, Mythical Lost Children 47), then this ending is surely not contemplated for Caryl Phillips's lost children.

The absence of a satisfactory end is also due to the author's particular use of the concept of empathy, or more precisely, to the absence of empathy exemplified by the lack of communication among members of the same family: talking about their own feelings and problems is "completely off the agenda" for the characters of The Lost Child (196), and especially for the lost children Ben and Tommy. This aspect is highlighted throughout the text by two different expressions of parental love which, according to Phillips, can sometimes be invasive and patriarchal - as in the case of Monica's father, 
Ronald Johnson, or Patrick Brontë - as well as totally indifferent - as for Julius Wilson. Both these wrong forms of love can only end up shaping people who will be deprived of both a history and a future.

Every chapter portrays some aspect of a disastrous relationship between parents and children, thus giving a particular racial and social meaning to the notion of being "lost" as a shaping motif. However, each chapter also explores the racial question and the origin of the multicultural nature of modern Britain. This is actually one of the most important themes addressed by the author, as it is connected to family ties and miscegenation, ${ }^{3}$ here embodied by two apparently distant situations: the condition of Heathcliff's mother who, according to the author, was a slave abused by Mr. Earnshaw in his Antiguan estates, and the marriage between the Caribbean student Julius and the white bourgeois Monica. By creating a connection between these different moments, the author reconnects the topic of miscegenation to both the slave trade and the trope of lost children seen as the product of mixed relationships and as people without history, as was the case for the slaves. Viewed in this light, one is tempted to assume that multiracial families can only produce lost children, or modern variations of the ancient myth: Heathcliff and Ben and Tommy can all be considered lost children because they share the same fate of self-destruction and loneliness which is related to their mixed origins and to their condition of "orphans." The tragic story depicted by Phillips does not provide a happy ending for them; in fact, from the beginning, Phillips underlines the difficulties facing mixed families, firstly by referring to the death of Heathcliff's mother during the sea crossing which should have led her to Britain (12), and then by moving to the twentieth century to portray the failure of Julius and Monica's marriage.

For the Caribbean Julius, the white Monica is just a trophy, a point of "arrival" (26) after seven years of attempts to achieve a position in the 1950s British scenario. On the other hand, Monica has decided to marry Julius not for love, but as a way of punishing her father Ronald (51), a suffocating patriarchal figure who has always tried to control and impose his own desires on his daughter. According to Ronald in fact,

Given all her advantages and ability, it made absolutely no sense to him that Monica should be throwing everything away by getting involved with a graduate student in history nearly ten years her senior who originated in a part of the world where decent standards of behaviour and respect for people's families were obviously alien concepts. (22)

Ronald's preconceived ideas about Julius are clearly distorted by the racist background of the postwar period in Britain, a mood that Julius is trying to fight not only through his mixed marriage, but also by means of his participation in an Anti-Colonial Club (29). Based on these considerations, it is evident that Julius and Monica cannot be happy, and Phillips further highlights this situation by insisting on their racial and personal differences: "Julius] had long ago given up insisting that [Monica] listen to his boring talks about the future of his nonsensical stupid country, but as he sat down, she found herself once again dismayed by the gaudy African shirt and leather sandals he had

3. Miscegenation is a recurrent topic in Phillips's works. In The Nature of Blood, he emphasizes this aspect through the rewriting of Othello and Desdemona's marriage in Shakespeare's Othello (1603). In Cambridge (1991), the author addresses the topic from the opposite angle, by describing relationships between black women and white men in the colonies, that is between slaves and masters. Those young women were called "housekeepers" and became the mistresses of white masters, to ultimately face "an even worse destiny, having been used by degenerate Englishmen who no doubt simply came [to the West Indies] to make a quick fortune and return [to England] rejoicing at their success" (52-3). This situation clearly reflects the position of Heathcliff's mother, as Phillips imagines it in The Lost Child. 
taken to wearing" (39). Their different backgrounds, due to their racial identification, makes Julius's interest in the political life of his country of origin nonsensical to Monica, and his extravagant African clothes, which appealed to her at the beginning of their relationship, are now the symbol of their disastrous marriage, as well as of their dissimilarities. They actually have different standpoints about their family's future; while Monica simply wishes to have "a better kind of man than my father" (51), by means of his marriage Julius has consciously tried to challenge the racism that lies at the bottom of the xenophobic British reality. His marriage is a sort of redemption for him, a way to escape from the oppressive heritage of colonial slavery. In this regard, as for Othello in The Nature of Blood, miscegenation reveals a desire for a form of assimilation which would "annihilate the very mark of his racial subordination, his black skin" (Dawson 93), and would function as a fixed signifier allowing him to affirm his social achievement and his attempt to reach a sort of personal "whiteness."

Furthermore, Julius keeps on fighting for his full assimilation into the British mother country at the expense not only of his English wife and their children Ben and Tommy, but also of his previous family. Like Othello in The Nature of Blood, in fact, Julius has left his first family in the Caribbean, thus demonstrating his chronic inability to carry out his parenting skills. It is not surprising, therefore, that he is not able to establish any kind of parental relationship with his "English" children Ben and Tommy. Actually, their relationship is simply not recorded in the narration, and the author's silence about it conveys Julius's indifference. After the collapse of his dream of assimilation into English society, in fact, he just prefers to abandon them by returning to his native island in the Caribbean, no longer making contact with them:

Shortly after the talks between the British government and the delegation from his country collapsed, Julius applied for a job as a lecturer at the institution that had awarded him his bachelor's degree. [...] He knew there was no way he could share the news of their falling-out with his wife and give her the satisfaction of being proved right. [...] $[\mathrm{H}] \mathrm{e}$ had no real interest in giving anything to this country that had now been his home for over a dozen years. After all, what had he received in return from these people? A latenight beating from some hooligans, and the problem of an increasingly sloppy wife who insisted that the children call her Mam as opposed to Mommy, or even Mama, and who long ago seemed to have relinquished any appetite for improvement or accomplishment. [...] The opportunity to go home and make a contribution, and perhaps try again to revise his dissertation and turn it into a book - this, he told her, was his true future. $(49-50)$

Julius's attempt at assimilation into the British system has failed both in the public sphere - due to the shipwreck of the diplomatic relations between the British government and his country - and in his private life - because of the collapse of his marriage: he cannot find support in his wife, so that he transfers the frustration for his personal defeat also to the relationship with his sons. His family has turned into a "problem" for him; he cannot recognise even his own children, maybe because they are too English and they belong to the country which has never accepted him as a real citizen. Hence, he needs to return home in order to find a place where he can feel accepted; however, Julius's egoism does not take into consideration either the boys' needs, or his duties as a father, and the youngest son Tommy particularly suffers from his father's absence.

Tommy is depicted as a perpetually starved boy: "It seemed like he was always starving, which didn't make any sense as Mam always wrapped us both some dinner money 
in pieces of paper and left it for us on the kitchen table" (144). From this description, however, it seems quite obvious that his hunger is more emotional than material: " [...] Tommy always wanted to talk about the same thing. How come our dad never came to see us? Didn't he care for us anymore?" (146) The absence of a paternal figure, along with the failure of communication between the boy and his mother Monica, leads him to become attached to Monica's new boyfriend, Derek Evans, who will finally turn out to be a pederast. Tommy's tragic fate, however, is shrouded in mystery: indeed, Phillips chooses (not) to describe his actual end through Monica and Ben's confused memories and fragmented assertions, thus exploiting the potentialities of the plot's fragmentation, a device which contributes to increasing the reader's difficulty in interpreting the events of the narration. Actually, Phillips uses narrators and focalizers throughout the text to blur the distinction between inside and outside and between different points of view; thus, Monica's mental unbalance, due to the collapse of her life as a consequence of the disappearance of her child and her loneliness, is just sketched or kept under wraps by the author, who thus exploits a modernist technique which delegates the narration to the unreliable Monica. This narrative discontinuity allows the author to jump from one subject, and one historical moment, to another one, going from a flashback on the Brontë family, to the narration of the everyday life of Monica and her children after Julius's departure. In this way, the recognition of responsibility for Tommy's fate or for the dissolution of the family remains ambiguous, since Monica affirms that she fought for her family until the end (237), while Ben does not agree with her: "More than anything, he wanted to believe that she'd done the best she could, but he just couldn't get his head around the fact that she'd given him away" (202). This disagreement between mother and son is further evidence of the way in which outside circumstances weigh on relations within the family, making the reciprocal understanding even more difficult. As victims of this situation, the members of the family are uprooted from familiar places, while the anguish of separation is combined with the dissolution of all sorts of identity, from both a racial and a domestic standpoint (Okazaki 93).

The chance to create a stable domestic situation is denied also in the relationship between Ben and his grandfather Ronald. The latter has read about Tommy's disappearance in the newspaper; however, he has never participated in his grandchildren's lives, and he has never paid attention to their wellbeing as a consequence of his disastrous paternal experience with his daughter Monica. He thinks that " [...] he simply couldn't get in touch because Monica would never have entertained any sympathy from him" (206); thus, even after Monica's breakdown, he decides to stay out of Ben's life, although he would actually like to ask his grandson many questions. Their rupture is irreconcilable, and this situation deprives Ben of the opportunity to find a sort of paternal love or affective bond. As Okazaki points out: "Ties to other people, the bonds of love, are as important as ties to place, in maintaining the groundedness and connectedness upon which we rely for emotional and psychological stability and fortitude" (Okazaki 92), and this comfort is denied to all the characters of the novel.

The lack of a strong and affectionate bonds between parents and children is at the basis of other catastrophic relationships, as is the case of Monica and Derek Evans. Actually, from the beginning of their relationship, the Englishman does not show any real interest in her; Monica's attachment to him can be explained, therefore, only through her desperate need for love caused by her father's indifference and the sad end of her 
marriage. In other words, this is the only kind of tainted love that she can recognize and accept because of the lack of affection from which she suffered in the past in her relationships with her father and her husband Julius; her devastating sense of vulnerability has affected her since her youth, and it equates her infant abandonment and her romantic betrayal.

The origins of the dysfunctional family relationships Phillips describes may be traced back to the nineteenth century, in particular to the British family relationships of the past since, generally speaking, "Phillips's accounts (fictional or otherwise) span generations and epochs, linking up the present with the all too often unacknowledged past of colonial and genocidal encounters [...]" (Okazaki 88). Therefore, this link between past and present is characteristic of Phillips's fiction, and his purpose is to "chronicle the impact of such phenomena of colonialism, the slave trade, migration of labor, on the various protagonists involved" (Okazaki 88).

The incorporation of a separate chapter focussing on Emily Brontës family in the middle of The Lost Child can be read in this perspective. Even though its integration could seem quite arbitrary at first sight, by referring to the family of the author of Wuthering Heights Phillips intends to open a window not only on the nineteenth-century British society, but also on the problematic questions of the slave trade and of the lost children as they are addressed in Brontë's novel through the mysterious origins of Heathcliff. The complex nature of the father/son relationship is, therefore, directly narrated also by Emily Brontë, in a re-evocation of the English literary past. In this regard, the difficult relationship between Patrick Brontë and his son Branwell serves as a subtext in order to demonstrate to what extent family conflicts are not limited by temporal or class distinctions. Furthermore, Phillips's peculiar re-reading of the English literary canon and its integration into the novel is possible thanks to continuous changes of perspective, which create a polyphonic dimension breaking down the temporal restrictions and the boundary between reality and fiction.

Patrick Brontë appears as a paternal archetype, the patriarchal and despotic figure which inspired the ambiguous relationship between Mr. Earnshaw and Heathcliff depicted in Wuthering Heights, as well as the repressive and inadequate fathers represented in The Lost Child. Indeed, Patrick Brontë can definitely be considered as one of the antagonists of Phillips's novel and, in the author's imagination, his parental inadequacy is confirmed by his strict behaviour towards both the dying Emily and the unruly Branwell. In particular, his paternal rigidity is described through his refusal to take care of his daughter:

[Papa] has shown no desire to present himself at the bedside of his ailing daughter. Half the family gone, but still, he refuses to bestir himself and offer his fading Emily the comfort of his company. His stern demeanour and distant sentiments appear to be entirely unaffected by the predicament of his poor child. (106)

On the other hand, the relationship with Branwell is complicated by the lack of communication and reciprocal comprehension:

[B]etween father and son a gap widened by expectation and disappointment. The one feeding the other. $[\ldots][\mathrm{H}]$ is heir was wasting his gifts and gratifying himself in the taverns of the capital. When Branwell finally returned, the two proud men looked upon each other and knew instantly that the time for conversation had passed them by somewhere on the road between Haworth and London. [...] [T] he stubborn son understood that his disinterest in the rigours of study meant that he might soon be introducing failure into 
the world of his father. [...] Papa made it clear to Branwell that there would be no further sympathy or help, which served only to further stoke the fires of resentment between them. (107)

Therefore, starting from these descriptions of the Brontë family scenario, and considering Phillips's re-reading according to which Mr. Earnshaw would be Heathcliff's father, it is also possible to assume that Branwell is the model for Heathcliff. In this light, Phillips's investigation of the past fulfils the function of supplying a historical background for his novel which suggests the close connection between family conflicts and social and cultural representations. This framework is built around a reconstituted knowledge of history, which involves "bringing to visibility the personal (hi)stories, subjectivities and voices that official reports have attempted to render invisible" (Okazaki 90) - in this case the voices of Branwell Brontë and of his fictionalized alter ego Heathcliff, as well as of the black children Ben and Tommy. In this tight connection between history and literature, the role of intertextuality is to "smooth an outsider's passage towards acceptance by insiders" (Sell 202), which means that the invention of a story involving the Brontë family helps the reader to perceive the link, through stories of fathers and sons, between the contemporary story line and the history of slavery in Britain. Moreover, by suggesting that Heathcliff is the son of Mr. Earnshaw, Phillips seeks to fill the most important gap in Brontë's novel, that is the question of Heathcliff's origin, the mystery which has fascinated so many readers, and he tries to do so by writing a parallel story which is not a mere re-writing of Brontë's text, but a sort of comment and a veritable dialogue with nineteenth-century British fiction and history. It is for this reason that Phillips's Heathcliff is not identical to Brontë's, thus demonstrating the author's desire to elicit an imaginative response on the part of the reader. Actually, Phillips's emphasis is concentrated only on the beginning of Heathcliff's story, a moment which implies his own process of identity formation and involves the abandonment of a foreign past and the embrace of a European future which is bright only in appearance. Phillips's surprising rewriting of the circumstances of Heathcliff's birth can generate a sense of estrangement in the reader, who knows that the original character had neither father nor mother, but at the same time it emphasizes the emotive and empathetic weight of Heathcliff's story in relation to that of Tommy and Ben. Although they are temporally distant, these different young outcasts, or lost children, share the same tragic experience in their parental relationships, and they are representations of an alienating system and a microcosm of unexpressed emotions. In this regard, Phillips provides an intertextual background for the interpretation of contemporary race relations, thus creating a possibility for empathy between the reader and the characters of Phillips's work, so that "the cognitive challenge posed by intertextuality may become an exercise in intercultural empathy which, if carried out with any degree of success, will equip us better for life in a multicultural or cosmopolitan society" (Sell 209). This process is possible because, according to Jonathan Sell, an intertextual fragment can be understood only thanks to the reader's literary competence, the reader's familiarity with other texts, themes, and society's mythologies (204). So, The Lost Child's story would not be totally recognizable without its connection to one of the fundamental human mythologies, that is the lost child trope used also by Emily Brontë.

In this light, Tommy and Ben, like Heathcliff, can be actually considered as both outcasts and lost children who have to bear the weight of their difficult past. They are lost 
children because they have been abandoned by their parents and they are looking for a mythical rescue which, however, will not occur. This situation leaves them languishing in dark variations of the ancient plot. In fact, fate will not be merciful with either of them: if on the one hand, Tommy is deprived of any hope because of his miserable encounter with Derek Evans, on the other hand, Ben's destiny is also uncertain. Even his last possibility to meet a paternal figure in his adoptive father Mr. Gilpin is, in fact, disappointed because of their unsatisfying relationship. Hence, Ben will not benefit from the same rescue as Phillips's Heathcliff, made possible through his encounter with his real father Mr. Earnshaw, and this difference in fate could be related to the historical contexts involved. The racial question comes back, therefore, also in relation to the lost child trope: Ben and Tommy may not find final relief because they are sons of the black Julius Wilson, while Mr. Earnshaw, as a white man, can claim the paternity of his son Heathcliff, thus making the child's integration into society possible. The patriarchal system created by Phillips gives, therefore, more relevance to the paternal genealogy than to the maternal role so that, according to Barbara Estrin, the lost child plot can be interpreted as "a vehicle for the imposition of a male order that renders gender as well as race key players in the drive for mastery" (Mythical Lost Children 23). Thus, the female genealogy given by Monica and Heathcliff's mother ends up being of marginal importance.

Moreover, Monica's weaknesses also contribute to the disastrous conclusion given to the foundling theme. Her breakdown firstly provokes Tommy's desire to be an orphan (159), then it leads to his mysterious disappearance. In this way, Phillips demonstrates that the mythical expectation of rescue associated with the classic lost child plot can be "annulled by fabricating the loss and that the life-link in the myth can be actualized [...] only through a death-wish" (Estrin, Mythical Lost Children 35). There is no recognition or salvation for Tommy, or for his brother Ben; Phillips's story is, therefore, a narration of endlessly disillusioned relationships, in which the classic happy ending traceable in the foundling narration (Estrin, Theorizing Foundling and Lyric Plots xiv) cannot be expected, since the lost children are oppressed by the weight of their past and by the failure of their paternal figures. From this perspective, the notion of "the ghosts of strangers" coined by Calbi can be used also when referring to the "strangers" Tommy and Ben, who have become ghosts themselves, people "whose traumatic and messy memories cannot be entirely dispelled or wholly assimilated, and do not fit in with the linear, homogeneous, and empty time of historicism" (Calbi 51). This situation inevitably condemns Ben and Tommy to a life shaped by loss, or to death.

In conclusion, in The Lost Child Caryl Phillips manages to combine his favourite themes, such as the racial question and the topics of the outcast and the lost child, to a true and deep investigation of the human soul and family bonds. His exploration of these issues is strongly connected to English history and the English literary canon, two aspects of Englishness which depend on the authority of blood lines. However, despite the painful ending of most of his characters, the very conclusion of the text leaves a glimmer of hope for the future of the multiracial British society:

They [Mr. Earnshaw and Heathcliff] have survived the worst of the upheaval, and the man knows full well that their odyssey across the inhospitable moors will soon be at an end. He seizes the exhausted boy's hand in his own and focuses his attention on the ghostly blackness before them. Let's go now. As they move off, the boy feels the man squeezing his hand ever tighter. Let go of me. The rain has stopped, and the clouds are 
clearing, and above them it is now possible to see a constellation of silver stars in the night sky. We're going home. And then the man repeats himself. The boy looks into the man's face, and again he asks him to please take him to his mother. Home. Quick, come along, let's go. Between sky and earth the boy skids and loses his footing, and the man stoops and picks him up. For heaven's sake, one foot in front of the other. The boy stares now at the man in whose company he has suffered this long ordeal, and he can feel his eyes filling with tears. Please don't hurt me. Come along now. There's a good lad. We're nearly home. (259-60)

Phillips's idea of "home" at the end of the novel is complicated by the mixed origin of Heathcliff - and of the author himself. Mr. Earnshaw, in fact, has consciously decided to separate his son from his ancestral land to take him to a country which will probably never accept him, as Julius Wilson's fate demonstrates. The problematic search for a place to call "home" affects also Phillips's life, so that he describes himself as a man with "three homes" and "able to turn my back on Britain" (Phillips and Sharpe 161). As the Caribbean author affirmed, when growing up, he sometimes felt like an outsider, and this feeling is "very commonplace in British life. [...] The question of parentage, the question of belonging, is very central to Wuthering Heights, and some of those echoes in that novel obviously began to resonate with me when I was thinking about the more contemporary story" (Phillips in Simon). Therefore, Phillips has decided to engage with Britain's literary history in order to deal with the problematic "historical nonsense" (Phillips and Sharpe 161) related to the complex question of belonging that has affected black people throughout the centuries. His rewriting of Wuthering Heights, one of the most important texts of the English literary canon, can be read also as a device used to come to terms with this past. Mr. Earnshaw and Heathcliff have to take small steps, "one foot in front of the other," in order to reconstruct their relationship, just as white and black people, fathers and children, have to learn to love and respect each other. However, in spite of their differences and the difficulties they will probably meet on their mutual path, the open ending of the novel demonstrates that there may still be a hope to establish a better relationship and to find a reciprocal understanding for Heathcliff and his father Mr. Earnshaw; and this is also Phillips's greeting for the future of Britain and of all its father/son relationships.

Alessia Polatti

University of Verona, Italy

\section{Works Cited}

BRONTË, Emily. 1847. Wuthering Heights. Minneapolis: Lerner Publishing Group, 2014.

CalBI, Maurizio. “'The Ghost of Strangers': Hospitality, Identity and Temporality in Caryl Phillips's The Nature of Blood." Journal for Early Modern Cultural Studies 6.2 (Fall/Winter 2006): 38-54.

CuIngman, Stephen. "Other Voices: An Interview with Caryl Phillips." Salmagundi 143 (Summer 2004): $112-40$.

Dawson, Ashley. ““'To Remember Too Much Is Indeed a Form of Madness': Caryl Phillips's The Nature of Blood and the Modalities of European Racism." Postcolonial Studies 7.1 (2004): 83-101.

EstRIN, Barbara L. The Raven and the Lark: Lost Children in Literature of the English Renaissance, London: Associated UP, 1985.

—. "I had rather to adopt a child than get it': Mythical Lost Children in Caryl Phillips's The Nature of Blood." Ariel 34.4 (2003): 23-50.

-. Shakespeare and Contemporary Fiction: Theorizing Foundling and Lyric Plots. Plymouth: U of Delaware P, 2012. 
Racial Genealogies and Intertextuality in Contemporary Britain: Caryl Phillips's The Lost Child

OKazAKI, Hank. "Dis/Location and 'Connectedness' in Caryl Phillips.” Journal of West Indian Literature 6.2 (May 1994): 88-96.

PhiLLIPS, Caryl. Cambridge. London: Bloomsbury Publishing, 1991.

-. 1997. The Nature of Blood. London: Faber and Faber, 1998.

—. The Lost Child. New York: Farrar, Straus and Giroux, 2015.

Phillips, Caryl, and Jenny Sharpe. "Of This Time, of That Place." Transition 68. Indiana University Press on behalf of the Hutchins Center for African and African American Research at Harvard University, 1995. 154-61.

SeLL, Jonathan P.A. "Intertextuality as Mimesis and Metaphor: The Deviant Phraseology of Caryl Phillips's Othello." Odisea 9 (2008): 201-11.

Simon, Scott. “'Lost Child' Author Caryl Phillips: 'I Needed to Know Where I Came From'.” 21 March $2015<$ http://www.npr.org/2015/03/21/394127475/lost-child-author-caryl-phillips-i-neededto-know-where-i-came-from>. Consulted 30 January 2017. 